\title{
Gender Subtexts in Collusive Linkages between Bhadralok Ethos and Colonial Law in Select Daroga Daptor Narratives
}

\author{
Tapti Roy \\ PhD Research Scholar, Department of English, Jamia Millia Islamia. ORCID Id: 0000-0001-9354- \\ 1882. Email: subterraneanhominin@gmail.com
}

\begin{abstract}
Crime writings can be said to have originated in Bengal in the last decades of the $19^{\text {th }}$ century with the emergence of narratives of seemingly true criminal investigations compiled by real life darogas like Girish Chandra Bose, Priyanath Mukhopadhyay, and Bakaullah. These non-canonical accounts though rendered in simplistic narrative techniques to report cases which may appear inconsequential to present day readership not only set the field for more complex fictional works of criminal investigation but also laid the foundations of a new genre of vernacular popular fiction favoured till date. It can be mentioned here that the criminal investigation accounts of Priyanath Mukhopadhyay were serialised as Daroga Daptor for a significant span of a decade which owing to its elements of thrill, mystery, and instruction were immensely coveted by the readers. The significance of the Daroga Daptor narratives for the purpose of the paper however lies in its reflections of the contemporary socio-legal setup comprised of responses towards sexual mores, socioethical strictures, and gender positions. In this context, the objective of the paper is to analyse select narratives of Daroga Daptor with females as victims or accused, namely the novel Adarini and short story "Promoda". Initiating the process with an overview of the office of the daroga emphasising on the popular associations of daroga with sloth and corruption, the paper will note the manner in which Daroga Daptor marked a paradigm shift in popular imagination with regards to the intellectual abilities and sensibilities of daroga. Proceeding with the analysis of the aforesaid narratives, the paper by emphasising on the $19^{\text {th }}$ century gender roles with respect to hypermasculine bhadralok norms and tenets of colonial law will situate the women characters as existing in an ambiguous position within the colluding grounds of the two apparently opposite masculine factions. The paper thus, will establish the $19^{\text {th }}$ century native female body as a passive pliable vessel for various ideological experimentations reading them as perpetually incarcerated within the dynamic limits of an efficient, promptly adaptive, and multifariously hegemonic masculine order. Keywords: $19^{\text {th }}$ century Bengal, Gender relations, Daroga Daptor, Crime Writing, Bhadralok, Priyanath Mukhopadhyay
\end{abstract}

\section{Gender Subtexts in Collusive Linkages between Bhadralok Ethos and Colonial Law in Select Daroga Daptor Narratives}

Bengal as the seat of British Empire holds a prominent place in the colonial history of India as not only did it serve as a terra firma for various experimental administrative, fiscal, and legal reforms, but also provided a site conducive to the germination of nationalism. Along these lines can be regarded the upheaval of the extant rudimentary judicial framework under the aegis of Lord Cornwallis that led to the organisation and consolidation of police force under the Magistrate and darogas. In this context, the paper aims to consider two specimens of Daroga Daptor narratives 
by Priyanath Mukhopadhyay, namely the novel Adarini and short story "Promoda" to examine the manner in which these narratives rather than being mere written accounts of mystery and detection for public entertainment served as mouthpieces for propagating the hypermasculine bhadralok agenda devised on discourses of jeopardised native masculinity ostensibly reflected in expatiations around disquisitions of spirituality, sexual purity, and restraint employing female body as a universal signifier.

Emerging in the later decades of the 19th century, narratives of Daroga Daptor can be read as the origins of crime and detection genre in Bengal prior to the advent of well-defined and culturally sophisticated sleuths such as Saradindu Bandopadhyay's Byomkesh or Satyajit Ray's Feluda. Daroga Daptor is a collection of non-canonical presumably authentic accounts of criminal investigations undertaken by darogas or detective inspectors employed with the colonial police. Despite being a popular genre till date as can be gauged from the popularity of Lalbazar accounts of Supratim Sarkar, in terms of research Daroga Daptor genre has received scant scholarly attention and remains in its nascent stages. Recent developments include a translation of ten women-centred narratives of Bakaullah and Priyanath Mukhopadhyay from Bangla to English undertaken by Shampa Roy in her work True Crime Writings in Colonial India which furnishes the short story "Promoda" for the paper. The narratives included for analysis have been carefully selected owing to the portrayal of women situated on social extremes of chastity and promiscuity providing a healthy estimate of the stance towards sexual mores of 19th century Bengal.

Since its inception, the office of the daroga has been frowned upon for the want of rightful decorum and sensibility amongst its earlier occupants which could be attributed to faulty legal formulations, administrative bottlenecks, and shortness of pecuniary returns (Chattopadhyay, 2000 , p. 57-59). Based on the contradictory policy of allocating lowest possible funds to secure finest services, the office of the daroga in reality attracted men of questionable ethical or social character as can be read in the work titled Miyajan Darogar Ekrarnama or The Confessions of Miyajan Daroga anonymously published in 1869. Priyanath Mukhopadhyay, in the aforesaid framework represents an appropriate choice for the paper as he alongwith Girish Chandra Bose mark a paradigm shift in the manner in which the office of the daroga was conceived within the ranks of colonial administration and contemporary popular imagination. Mukhopadhyay who completed 33 years of service with Calcutta Police retiring in 1911 later engaged himself with compiling seemingly authentic accounts of detection and criminal investigations conducted during his years of service (Sarkar, 2020). It has to be noted here that the major characteristic of Mukhopadhyay's works being the element of spine-chilling thrill and instructive entertainment, not all accounts comprising the body of his extensive Daroga Daptor detail memoirs of personal involvement but are often adapted from newspaper articles or reports of crimes and prosecutions. Thus, Mukhopadhyay can be assumed to be an embodiment of the attributes of the highly sought for superior class of men belonging to upper castes gradually trickling into the ranks of Daroga not only as apparent protectors and buffer upholders of colonial models and dispositions, but also live treatises of emergent Hindu bhadralok morality and domestic ethos. This can be observed in the construction of Daroga Daptor narratives of Mukhopadhyay which serve a didactic purpose by disseminating prescriptions of feminine behavioural proprieties determined to be practised infallibly within a discursively sanctified often rigid Hindu domestic space. To serve this purpose, besides offering accounts of criminal investigation, the narratives also undertake as a fundamental 
function the education of masses with regards to the intellectual investments involved in the process of detection as carried out by the office of the daroga therefore attempting to neutralise to a certain extent the negative connotations of the said office.

Written in Bangla Adarini is a non-canonical novel published in 1887 replete with the ordeals of the eponymous character, alternately known as Haridasi and her grandmother Tinkori Bewah. The narrative of the novel provides an intricately detailed account of the orphaned Adarini's strenuous escapades to preserve her chastity from the unsolicited advances of Jagat Singh, the native local zamindar of Maruchar. Adapted from unaccounted secondary sources Adarini, rather than being a description of bloodcurdling criminal investigation and consequent prosecution of the deviant sexual behaviour is modelled as a treatise of ideal Hindu female behavioural norms aimed at instructing women through example of the virtues of unconditional conformation to domestic ideals of sexual purity. An opposite trend can be studied in "Promoda" where unrestrained sexuality on the part of Hindu women depicted as deviation from standard norms of kinship is deemed injurious to the social order. The narrative recounts the illicit liaison of Promoda, the eponymous character with her lover Harimohan Ghosh resulting in the brutal murder of her husband Nabakumar Basu and the resultant investigation and trial (Roy, 2021, p. 126-144). Interspersed with advisory on proper female behaviour drawn upon the principles of sanctity of Hindu household and the intrinsic licit sexual contract inherent therein, the narrative condemns freedom of sexual expression especially in females. The paper will attempt an analysis of all the women characters in the aforesaid narratives situated in the contemporary milieu as ideal instances of hypermasculine Hindu purity and the consequences of lapses in adhering to the said code that effectively marginalised a substantial section of contemporary society especially women under the pretext of conservation of culture.

The birth of bhadralok nationalism in later 19th century post the advent of Crown in the scene of colonial administration in Bengal is closely linked with the reworkings of Hindu nationalism fuelled by a desire to reclaim native masculinity oppressed and challenged by the White administrators. Hence, in order to situate the opposing stances of three women regarding sexual purity, it would be useful to use Hindu revivalism and its revision of the domestic scene of the 19th century as a frame of reference. Colonial masculinity derived its strength from sustained discursive attacks on native masculinity branding it as effeminate, immoral, and physically fragile as can be observed in the comments of George Warrington Steevens, a leading British journalist (1899, p.75-76) or that of Lord Macaulay in his portrayal of Raja Nuncomar a revenue officer of Bengal as contained in his essay Warren Hastings (Macaulay, 1886, p.30-36, 57-67). Failing to envision themselves as equal status participants in colonial administration engendered a cantankerous ambivalence in the native males which oscillated between a miscalculation of their respective selfhoods and a desire to contend with the colonial culture leading to an exhaustive investment for upholding the purity of the domestic space. Disenfranchised and stripped of erstwhile gender based privileges in the external world, the native male turned to the realm of domesticity to seek amends "for all the work and relations there that lay beyond personal comprehension and control" (Sarkar, 2001, p.36). Based on the ghar/bahir dichotomy and its extensions in the form of inner/outer, spiritual/material or animal/godlike, the Hindu nationalists sought to undertake reforms that established the native women at an equivalent degree with the indigenously revered national female figures. Thus, New Patriarchy as a norm was envisaged by 
bhadraloks as a highly selective enterprise aiming to dextrously adapt with the social transition in the external world and simultaneously not to effectively destabilise the socio-religious status quo of the old order manifested in native kinship structures. The responsibility of maintaining the sanctity of the inner space in such an arrangement was duly shifted to the domestic faculties of women who were expected to be selectively educated, pure, self-sacrificing preservers of the conventional orders of traditionally prescribed female virtues (Chatterjee, 1993, p.127).

It is in this context that one may locate the narrative of Adarini portrayed in the eponymous novel as an epitome of traditional female virtues of chastity and sexual abstinence explicated for emulation by contemporary women. It is ironical however, to note that a text intended for the moral instruction of women is addressed exclusively to men which can be a probable indicator of the dismal literacy rates amongst the female colonial population where the privilege of education, especially in English was restricted to bhadralok families (O'Dell, 2014, p.539). This situated them as "as a kind of "portable property" ... that it allowed them, through the metonymic function of their degrees, to make a claim for the otherwise elusive powers of Englishness (O'Dell, 2014, p.542) reflected in exerting, through a bhadralok male solidarity, a consistent authority and influence over the native female physique and psyche. Additionally, styled as a naricharitra the text is a compendium of virtues desirable in a sati viewed through the lens of bhadralok which instantly negates as sacrilege the participation of the woman in the process of her own representation to be habitually appropriated by an agency external and often contradictory to her material presence. This can be traced in the following statements of Adarini.

No matter the amount of torment people inflict upon a woman, irrespective of the iniquities laid on her path, if she is firmly committed in her heart to the pursuit of dharma, aware of the nobleness of it, then no force will ever succeed in persecuting her for she is safeguarded by the Lord Himself ... Dharma is superior to the life of a woman. Who can deny this. (Mukhopadhyay, 1887, p.37) (Translation mine)

At another instance struggling to escape the clutches of Jagat Singh, Adarini speaks, "Can it be in your power to use force on me, how you can ever contemplate tarnishing the sati dharma of a sati woman!" (Mukhopadhyay, p.47) (Translation mine)

The above statements are indicative of the 19th century tendency of interpellating the body of the woman in a discourse of ethical servitude that in reality is directed at systematically repressing her sexual agency thus posing no apparent benefit to the validation of her social or legal position within the native bhadralok realm. On similar lines, Adarini's lack of consent towards submission to Jagat Singh's carnal desires cannot be read as an assertion of female subjectivity as it stems from the popular norms of purity and pollution instated by and fortified through numerous egocentric exchanges in the theatre of bhadralok masculinity. Not arising from Adarini's realisation of her own sexuality, this lack of consent can only further the agenda of situating women as lesser beings and hence ambiguous stakeholders in the native colonial bhadralok setting. Poetic justice is indeed the goal of the narrative whose denouement consists of the noble sati dharma of Adarini upheld through the conviction of Jagat Singh by colonial law. The narrative in this sense reflects placatory manoeuvre of viewing the ideologically disparate entities of native masculinity and colonial law through a single lens of native morality thus effecting a conscious 
amnesia towards the palpable cantankerous concerns that remained crucial to the delineation of a discrete nationalist bhadralok identity in the 19th century.

In the second text under consideration "Promoda" a passing mention is made of a boishnobi dwelling as a mistress, till her demise, with Nabakumar Basu prior to his marriage to Promoda. The fact that his marital prospects had been jeopardised owing to his liaison with the boishnobi is promptly dismissed as extraneous to the case and not regarded as crucial to understanding the lapses in the moral character of the victim Nabakumar. It can be stated here that in 19th century Bengal boishnobis as practitioners of the sahajiya sect of Vaishnavism along with Darbesh, a borderline Muslim group, and other low caste groups sought to construct an autonomous social space for an alternate discourse of acceptance within religion which was facilitated by the teachings of Chaitanya preaching a monotheistic God away from mediation of priestly class besides being openly accessible to all excluded and marginalised sections. Hence, Vaishnavism, indoctrinating in its folds members of a varied cross-section of society irrespective of class, caste, gender, or religious affiliation, has been one of the crucial factors in determining the socio-cultural transitions in Bengal. Gaudiya Vaishnavism therefore, can be read as a loose gamut of heterodox practices simultaneously incorporating devotional songs as well as lewd lyrics for popular entertainment. Closely linked with the fortunes of its trader patrons such as Dewan Kristo Ram Bose of Shyambazar, the Subarnabanik Mullicks of Pathuriaghata, the Rajas of Sovabazar, and the Basaks to name a few, Vaishnavism thrived in the urban metropolis of Calcutta witnessing functionalist transitions in tune with the age where it was deemed a palpable threat to the bhadralok order founded on a concept of unerring decency established as normal. Commenting upon the unfavourable response of the bhadralok towards Vaishnavs, Sekhar Bandyopadhyay observes, "... these sects were stigmatised as assemblies of licentious low-caste people united to indulge in illicit sexual activities, with an ever-increasing number of bastards swelling their ranks. In this way, the high caste Hindu bhadralok distanced themselves from the members of the deviant sects." (Bandyopadhyay, 1997, pg.33). Hence, bhadralok Vaishnavism concentrated sustained efforts towards purification of sacred spaces tainted by sexuality by resolving the untidy plurality to evolve a modern Gaudiya Vaishnavism characterised by discipline and sexual restraint as can be observed in the works of Kedarnath Datta and Shishir Kumar Ghosh (Bhatia, 2017, pg 53-89).

The near absence of subjective agency of native women in 19th century has been articulated above alongwith measures to appropriate them as secondary spiritual spaces in the hypermasculine bhadralok discourse. The impeccably malleable and gullible subjectivity of women enclosed in domestic spaces can be attested by a number of literary tracts composed by them that emphatically advocating the virtues conducive to the propagation of native male version of Hindu identity simultaneously criminalised instances of female sexual expression. Therefore, the distinction between the genteel bhadramahila and the immoral boishnobi was conveniently rendered with the latter situated as a visible epitome of lasciviousness and thence dreadfully contagious to the mores of middle class respectability. Despite belonging to the bhadralok class usually defined by unwavering strictures, little criticism is directed at the victim Nabakumar for entertaining sexual connections with a boishnobi reflecting capricious standards of morality which treats the questionable social behaviour of men as an exception. It can explain the cause for which the boishnobi, untrammelled by niceties of extant social order in terms of 
sexual expression, was summarily dismissed to avoid foregrounding of the ambiguous foundations of the legal environment formed by the collusion of bhadralok morals and colonial sentiments implicit in tenets of colonial law.

Before delving into the exercise of commenting upon Promoda's crime, it would be worthwhile to consider the following statement of the investigating detective Daroga Bansiram:

... an ordinary woman like you can never outwit daroga Bansiram. You'll find out that Bansiram daroga never leaves a job assigned to him unfinished. Look here Promoda, you are just a woman. Whether you committed this murder because you were overcome by your feminine impulses, or because you didn't know any better, or because you were acting upon someone's advice, it's best that you don't hide anything from me. Consider this my final warning ... if Bansiram wants, he can save you and if he wishes he can also see you hang. (Roy, 2021, pg.138) (Emphasis in original)

The comment provides ample space to measure the prejudices perpetually dominating the homicide investigation conducted by daroga Bansiram with regards to the murder of Nabakumar Basu of Santoshpur by his wife, the accused Promoda. Despite the details of homicide investigation revealing the presence of Harimohan Ghosh, the alleged illicit lover of Promoda as an active accomplice to the murder, the burden of the title of the narrative is invariably borne by the latter alone. The uniqueness of the case lies in the fact that the accused was already determined prior to the onset of actual investigation process on the basis of gossip and prevalent prejudices against the essential reason and sensibilities of women and that no actual evidence tying Promoda to the murder was truly available. Fixing the locus of investigation on minor lapses of prescribed duty of a Hindu wife towards her husband like failing to prepare food for him and negligible others like not veiling her face and talking in a loud voice, Bansiram concocted subsequent several larger allegations that not only branded Promoda as a murderess but also tarnished her character irredeemably by establishing her as a lecherous fornicator and hence a potential threat to the sexual integrity of bhadralok men. The magisterial conviction of Promoda was then an exclusive result of an impulsive desire for displaying intellectual excellence and aggressive metaphorical exhibitionism on the part of daroga Bansiram flimsily camouflaged as divine justice incarnated as colonial law.

Promoda was eventually sentenced to death which provides a space for recalling a similar case, Queen vs Nobin Chandra Banerjee, 1873 with reversed gender associations where a wife was actually decapitated by her husband on the suspicion of infidelity. The case is centred on a supposed liaison between a young wife Elokeshi with Madhavchandra Giri, the mohunt of Tarakeswar Saivite temple, contrived clandestinely by the former's parents. Elokeshi's husband Nobin Chandra residing in Calcutta away from his wife, acquired knowledge of the supposed affair through rumours rife in the village and exacted confession of his wife. Pardoning her offences he attempted to move her away from Tarakeswar which was hindered by the musclemen of the mohunt resulting in Nobin Chandra decapitating his wife with a fish knife in a fit of violent rage (Sarkar pg 56-57). Contrary to the biases explicit in Promoda's case leading to the death sentence, the general public indeed empathised with Nobin Chandra moulding the case as an instance of punishment justly deserved for spousal infidelity. The instance was further read as an impious attack on the sanctity of holy conjugal contract, in extension an outrageous assault to the 
spirituality fundamental to the bhadralok imagination of the domestic space, hence unpardonable. Thus, the Hindu bhadralok class responded by registering a plea of mercy signed by about 10,000 people (Sarkar pg.58) which led to Nobin Chandra's eventual acquittal in the Calcutta High Court. Both the aforesaid instances when compared reveal a strongly disturbing side of bhadralok ethos and the nebulous rationale behind colonial legal code based on an unholy collusion of vested interests aiming to hegemonise the subaltern group of native women by depriving them of their basic human rights of representation. Evaluating Promoda's case on the said lines, Roy observes:

Without overtly challenging the wisdom of the extremely oppressive practices that had produced the circumstances whereby a young adolescent girl had found herself tied in an indissoluble union to a 50-year old sick man, the description of Promoda's marriage ... [conveys] the miserable injustice of what had happened to her. Because of its caste position and indigence, her family had felt compelled to marry her to a Kayastha man who was much older, had had a mistress for many years and who was willing to settle for a poor man's daughter since no one else wanted him as their son-in-law. (2017, p.147)

Instances such as these in both native and colonial history are latent expositions of a tendency of disregarding the acknowledgement and remedy of actual causes of aberrant behaviour emphasising only upon a rigidly enforced normalisation of apparently deviant bodies of women to the agreed standard code of men.

The above discussion allows a snippet view of a positively miniscule example of the otherwise complex politics of entanglement between the axioms of native masculine bhadralok identity and the codes of colonial legal system coexisting in a twin disposition of accord and discord with each other. When faced with the question of native women's agency it can be observed that there is collusion implicit in colonial law explaining the safe distance maintained by the same from native domestic spaces left to be governed by the egoist doctrines of spiritual purity and corporal pollution characterising the bhadralok masculinity. Inferring from the analysis of the women characters above it can safely be assumed that bhadralok domestic strictures employed the bodies of native women dynamically utilising them as vessels for experimentation with presumptively progressive spiritual domestic codes alongwith ideologically redefining them as active beneficiaries of the dubious design. This can be a potentially probable explanation for the absence of any large scale autonomous struggle by women for equality of agency and freedom of expression pitted against the intellectual consumerism of the colonial administration. Such efforts, if any, were usually confined to and defused inside the domestic space by assimilation with perpetually reconstructed ramifications of female sacrifice and honour within the mutative discourse of native spiritual supremacy over colonial materialism. Manipulating and regulating female sexuality which also involved prompt neutralising of deviant voices bhadralok socio-ethical norms and colonial legal codes colluded to dictate the manner in which native female as a physical entity was dogmatically re-imagined and played as a signifier for advertising respective civilizational codes within the mutual discourses. In this process the female bodies were systematically effaced to be replaced with impressionable, governable, and culpable infantilised humanoid subalterns complicit to functioning under ill-founded mechanics of panopticon 
instated under self-proclaimed guardianships of enormously partial, multifariously hegemonic social orders.

\section{References}

Bandyopadhyay, S. (1997). Beginning of Social Protest and Construction of the Community, c1872-1905. In Caste, Protest and Identity in Colonial India: The Namasudras of Bengal 1872-1947 (pp. 64-98). Curzon Press.

Bhatia, V. (2017). Unforgetting Chaitanya: Vaishnavism and Cultures of Devotion in Colonial Bengal. Oxford University Press.

Chatterjee, P. (1993). The Nation and its Women. In The Nation and its Fragments: Colonial and Postcolonial Histories (pp. 116-134). Princeton University Press.

Chattopadhyay, B. (2000). Crime and Control in Early Colonial Bengal 1770-1860. K.P. Bagchi \& Company.

Macaulay, T. B. (1886). Warren Hastings. Gressner \& Schramm. https://archive.org/details/warrenhastings02maca/page/n3/mode/2up

Miyajan Darogar Ekrarnama.(1957). Amal Gupta Ayan. https://archive.org/details/in.ernet.dli.2015.302600/mode/2up

Mukhopadhyay, P. (1887). Adarini: Satya Ghatana Abalambane Likhita Naricharitra. A.G. Sen \& Company. https://archive.org/details/in.ernet.dli.2015.290063/mode/2up.

O'Dell, B.D. (2014). Beyond Bengal: Gender, Education, and the Writing of Colonial Indian History. Victorian Literature and Culture, 42(3), 535-551. http://www.jstor.com/stable/24575896

Roy, S. (2017). Deviant by Design: Female Criminals in the Daroga Accounts of Priyanath Mukhopadhyay. In Gender and Criminality in Bangla Crime Narratives: Late Nineteenth and Early Twentieth Centuries (pp. 146-155). Palgrave Macmillan.

Roy, S. (2021). Promoda. In True Crime Writings in Colonial India: Offending Bodies and Darogas in Nineteenth-Century Bengal (pp. 126-144). Routledge.

Sarkar, A. (2020). Darogar Daptor: The Bengali Detective in His Own Words. https://www.researchgate.net/publication/344433666_Darogar_Daptar_The_Bengali_Detective_in_His_ Own_Words

Sarkar, S. (2018). Goyendapith Lalbazar: Ek Dozon Khuner Ruddhaswas Nepathyakatha. Ananda Publishers.

Sarkar, T. (2001). Hindu Wife, Hindu Nation: Community, Religion, and Cultural Nationalism. Indiana University Press.

Steevens, G. W. (1899). In India. William Blackwood \& Sons. https://archive.org/details/in.ernet.dli.2015.54051/page/n5/mode/2up

Tapti Roy is an Assistant Professor of English at the School of Humanities and Social Sciences, Sharda University, Greater Noida. Her research interests lies in the domains of Colonial Medicine, Gender Studies, Literature and Myth, Anthropocene and Posthumanism. Currently, she is researching on the nexus of nationalist connections and Western medicine in $19^{\text {th }}$ century Bengal. 